\title{
EQUiLIBRIUM
}

Quarterly Journal of Economics and Economic Policy

2016 VOLUME 11 ISSUE 4, December

p-ISSN 1689-765X, e-ISSN 2353-3293

www.economic-policy.pl

Beck, K. (2016). Business Cycle Synchronization in European Union: Regional Perspective. Equilibrium. Quarterly Journal of Economics and Economic Policy, 11(4), 785-815. DOI: http://dx.doi.org/10. 12775/EQUIL.2016.036

Krzysztof Beck ${ }^{*}$

Lasarski University, Poland

\section{Business Cycle Synchronization in European Union: Regional Perspective}

JEL Classification: E32; E50; F44; R10

Keywords: business cycle synchronization; regional economics; optimum currency area theory; Hodrick-Prescott filter; European integration

\begin{abstract}
The recent turmoil in the euro area once more forces the EU authorities to reconsider the future of further monetary integration. One of the most commonly used criteria for successful monetary integration in contemporary research is business cycle synchronization (BCS). Though BCS has been vastly described at country level, not as much attention has been paid to the degree of BSC at regional level. The topic is important for two main reasons. Firstly, determining the degree of BCS at the regional level can help in the assessment of monetary policy effectiveness on the country level, as well as give a point of reference for evaluation of prospective costs of participation in a monetary union. Secondly, there is a theoretical dispute within the optimum currency areas literature between the 'European Commission' and the 'Krugman' view that can be resolved to a large extent trough regional analysis. In order to assess BCS in the EU, HodrickPrescott, as well as Christiano and Fitzgerald filter to time series of real GDP for 24 countries, 82 NUTS 1, 242 NUTS 2 and 1264 NUTS 3 regions over the period between 1998 and 2010. The data was later used to create bilateral measures of BSC, which gave 276 observations on the country level, 3321 on NUTS 1, 29161 on NUTS 2 and 798216 on NUTS 3 level. The results of the analysis support the
\end{abstract}

(C) Copyright Institute of Economic Research

Date of submission: April 6, 2015; date of acceptance: September 4, 2016

* Contact: beckkrzysztof@gmail.com, Lasarski University, ul. Świeradowska 43, 02-662 Warszawa, Poland 
'European Commission' view and show a very high degree of BSC within EU countries. The country level analysis also reveals that within the EU there is a group of countries that could form an effectively working monetary union based on the BCS criterion.

\section{Introduction}

The turmoil in the euro area once more forces the EU authorities to reconsider the future of further monetary integration. One of the most commonly used criteria for successful monetary integration in contemporary research is business cycle synchronization (BCS). This paper attempts to assess the degree of business cycle synchronization at regional NUTS 1, 2 and 3 levels and for country pairs. This analysis allows to assess the extent to which each of the national central banks, as well as European Central Bank, can conduct monetary policy effectively. The higher the business cycle synchronization between two countries/regions, the better the ability of their central banks to conduct common monetary policy for these two countries/regions.

This article proposes the measure of business cycle synchronization based on the correlation coefficient of deviations of cyclical component of real GDP from trend. The measure is, then, used to establish which groups of countries can introduce common currency at a relatively low cost. Same measures are used to check the monetary policy effectiveness within countries.

Section 1 presents the literature review, which is mostly concentrated around the theory of optimum currency areas and business cycle synchronization at country and regional levels. Section 2 presents data sources and methodology used to construct the business cycle synchronization measure. Section 3 presents results and section 4 concludes.

\section{Literature Review}

The prospect of a monetary unification in economics is usually considered in the context of the theory of optimum currency areas (OCA), based on seminal works of Mundell (1961), McKinnon (1963) and Kenen (1969). Nowadays, the 'new' theory of optimum currency areas (Tavlas, 1993) also considers a more dynamic approach closely related to the works of Krugman (1993) as well as Frankel and Rose (1998) and their 'The Endogeneity of the Optimum Currency Area Criteria' hypothesis, as well as Mundell (1973a, 1973b). Both international (Grubel, 1970; Mongelii, 2002 
and 2008; Tavlas, 2008) and Polish (Nowak et al., 1999; Łon, 2007; Lis, 2008; Żyżyński, 2009; 2011; Osiatyński, 2011) economists have discussed the potential benefits and costs of introducing a common currency on the theoretical level. A more complex measure of countries' readiness to form a monetary union has been proposed by Bayoumi and Eichengreen (1997), who introduced a unified index based on nominal exchange rate volatility, trade intensity, trade similarity (intra-industry trade intensity) and differences in real GDP growth rate.

Empirical research in this area is very complicated due to the difficulties inherent in the attempts to measure with the measurement of potential costs and benefits. For this reason, researchers focus their attention on testing the conclusions from the OCA theory using two main approaches. In both cases, the authors try to find similarities in either economic shocks or business cycles; if there are strong, monetary policy and externally flexible exchange rate become very effective tools of common central bank.

The first approach uses the Structural Vector Auto Regression models (Blanchard \& Quah, 1989; Taylor, 2004) to identify economic shocks and was firstly utilized for OCA purposes by Bayoumi and Eichengreen (1993). They examined demand shocks among European countries and US census regions, and found out that regions in the US are characterized by a higher degree of cohesion. Using a similar approach, Dumitru and Dumitru (2011) found a significant role of idiosyncratic demand shocks among European countries, even some of its core countries. Beck and Janus, using SVAR approach, discovered low correlation of economic shocks among the Euro Area countries (2013) and a high degree of synchronization of shocks for V4 countries (2014).

The second approach is concentrated on the business cycle synchronization (BCS), and the literature on BCS has put high interest on parts of determinants. Using multi-equation approach, Imbs (2004) found evidence that trade, inter-industry trade, structural similarity and financial integration positively influence BCS, using data on Developed countries and states in the USA. He also found evidence for Endogeneity: direct and indirect of trade and financial linkages on business cycles synchronization. Results have later been reproduced on a sample of European countries by Siedschlag (2010), as well as Dées and Zorell (2011). Kalemli-Ozcan et al. (2009), in contrast with Imbs, found that financial integration influences business cycles synchronization negatively, using the single equation approach. They argue that cross-section analysis suggests a positive impact of financial integration on business cycles synchronization, but panel approach reveals the opposite effect. Beck (2013), using multi-equation approach reports intermediate effects of GDP per capita distance trough struc- 
tural similarity on business cycle synchronization and Chang et al. (2013) show the impact of similarities in ruling parties.

Complex analysis with sensitivity checks (Leamer \& Leonard, 1981; Leamer, 1983; 1985; Levine \& Renelt, 1992; Sala-I-Martin, 1997a; 1997b) has been performed for BSC by Baxter and Kouparitsas (2004). They employ extreme bounds analysis to several potential determinants of business cycles synchronization, but, besides the gravity variables, they only found trade significant. In a more recent approach, Böwer and Guillemineau (2006), using the same methodology but focusing their attention on the Euro Area, found only trade, economic specialization at industry level, fiscal deficits, price competitiveness and stock market differentials to be significant as business cycles synchronization determinants. In yet another attempt to use extreme bound analysis, Sachs and Schleer (2013) obtained significant results for institutional similarities and directions of structural reforms, but found trade, structural similarities and fiscal and monetary policy similarities insignificant in many of their specifications. Beck (2013), using Sala-I-Martin version of extreme bound analysis, discovered the robust impact of structural similarities and GDP per capita distance on BSC.

Gogas (2011), using the one equation approach, found positive effects of introducing common currency on BSC using sample of twelve European countries. On the other hand, Bordo and Helbling (2010) argued that increasing business cycles synchronization is a worldwide phenomenon. Lehwald (2012), using Bayesian dynamic factor model, argued that a great part of increased business cycles synchronization among Euro Area countries comes from worldwide tendencies, rather than the ongoing integration.

All research mentioned above was only taking into consideration countries as a unit of measurement. As noticed by Alesina and Barro (2002), the number of countries in the world is changing, but this does not necessarily mean that the number of OCAs is changing with them. As a result, the country perspective instantly eliminates the possibility of OCAs existing within countries or amongst parts of countries. In order to assess them, a lower level of aggregation is required, hence the regional perspective. For these reasons, this paper tries to concentrate on regional business cycles synchronization which did not gain as much attention in the literature.

Artis et al. (2009) find no evidence of convergence of regional business cycles for European regions and for the USA, and claim that BSC have been stable over 1982-2007. Correia and Gouveia (2013) examined business cycle synchronization in Portuguese regions between 1988 and 2010 and concluded that it had decreased over the period. Anagnostou, Panteladis and Tsiapa (2012), in a comprehensive research, found differences 
in regional BSC for 14 European countries that could be explained by trade and differences in the level of development. Marino (2013), on the sample of 12 European countries, found that changes in regional business cycle synchronization could be explained by distance and differences in economic structure.

\section{Data and Measurement}

In the investigation, only European countries with data available on regional level were taken into consideration. The list of all the countries and number of different NUTS 1,2,3 regions along with the number of possible pairs is available in Table 1.

Table 1. Data description

\begin{tabular}{|c|c|c|c|c|}
\hline Name & Country & NUTS 1 & NUTS 2 & NUTS 3 \\
\hline Belgium & 1 & 3 & 10 & 42 \\
\hline Bulgaria & 1 & 2 & 6 & 28 \\
\hline Germany & 1 & 16 & 31 & 427 \\
\hline Greece & 1 & 4 & 12 & 50 \\
\hline Spain & 1 & 7 & 17 & 51 \\
\hline France & 1 & 8 & 20 & 96 \\
\hline Italy & 1 & 5 & 21 & 104 \\
\hline Hungary & 1 & 3 & 6 & 20 \\
\hline Holland & 1 & 4 & 12 & 38 \\
\hline Austria & 1 & 3 & 9 & 34 \\
\hline Poland & 1 & 6 & 16 & 66 \\
\hline Romania & 1 & 4 & 8 & 42 \\
\hline Finland & 1 & 2 & 4 & 19 \\
\hline Sweden & 1 & 3 & 8 & 20 \\
\hline UK & 1 & 12 & 36 & 130 \\
\hline Czech & 1 & - & 8 & 11 \\
\hline Denmark & 1 & - & 5 & 10 \\
\hline
\end{tabular}


Table 1 continued

\begin{tabular}{ccccc}
\hline Name & Country & NUTS 1 & NUTS 2 & NUTS 3 \\
\hline Ireland & 1 & - & 2 & 8 \\
\hline Portugal & 1 & - & 5 & 27 \\
\hline Slovenia & 1 & - & 2 & 12 \\
\hline Slovakia & 1 & - & 4 & 7 \\
\hline Estonia & 1 & - & - & 5 \\
\hline Latvia & 1 & - & - & 6 \\
\hline Lithuania & 1 & - & - & 10 \\
\hline Sum (countries/regions) & $\mathbf{2 4}$ & $\mathbf{8 2}$ & $\mathbf{2 4 2}$ & $\mathbf{1 2 6 3}$ \\
\hline Maximum number of pairs & $\mathbf{2 7 6}$ & $\mathbf{3 3 2 1}$ & $\mathbf{2 9 1 6 1}$ & $\mathbf{7 9 6 9 5 3}$ \\
\hline Data Frequency & quarterly & annual & annual & annual \\
\hline nominal GDP/GVA Source & Eurostat & Cambridge Econometrics \\
\hline P (national level) source & Eurostat & \multicolumn{2}{c}{ Penn World Table } \\
\hline Period for filtration & $\mathbf{1 9 9 8 q 1 - 2 0 1 4 q 1}$ & \multicolumn{3}{|c|}{$\mathbf{1 9 9 1 - 2 0 1 0}$} \\
\hline Period for correlation & $\mathbf{1 9 9 8 q 1 - 2 0 1 0 q 4}$ & \multicolumn{2}{c}{ 19910 } \\
\hline
\end{tabular}

Source: own work.

For countries, quarterly data about nominal GDP and price level $(2005=100)$ from the first quarter of 1998 to the first quarter of 2014 obtained from Eurostat was used. The data was seasonally adjusted with X-13 ARIMA $^{1}$. For regions (NUTS 1,2,3), annual data of nominal gross value added (GVA) and the price level was collected. Due to a lack of data of the prices at regional level, the data of national price level has been used as a deflator. This is a common practice in regional research, including Sachs and Sala-I-Martin (1991). GVA data comes from Cambridge Econometrics, and the price level data from Penn World Table 8.0, both cover the 19912010 period. For comparisons between countries and regions, the data for 1998-2010 used. Longer periods have been used in order to get better results from the Hodrick-Prescott filter. For the same reason, quarterly data was used for GDP and prices and the national level.

\footnotetext{
${ }^{1}$ Newest method of season adjustment available to the author. For more detailed information: https://www.census.gov/srd/www/winx13/WinX13Doc.html (15.02.2016)
} 
To justify the usage of detrending methods, tests for the presence of unit root have been used. Since Nelson and Plosser (1982), there has been substantial disagreement over the nature of the GDP trend (Rudebusch, 1993) - whether it is deterministic or stochastic. Due to that fact, an ADF (Said \& Dickey, 1984) test was performed with two variations of the following equation ${ }^{2}$ :

$$
\Delta Y_{t}=\alpha+\beta t+\delta Y_{t-1}+\sum_{i=1}^{p} \gamma_{i} \Delta Y_{i-p}+\varepsilon_{t}
$$

where $\Delta \mathrm{Y}_{\mathrm{t}}$ denotes a change in real GDP, $\alpha$ is a constant term (drift), $\beta \mathrm{t}$ is a deterministic trend, $\delta$ is a coefficient on lagged real GDP and $\gamma_{\mathrm{i}}$ is a coefficient on i-th lag of change in real GDP and $\varepsilon_{\mathrm{t}}$ is a residual term. The number of lags has been chosen with Schwarz information criterion. In the first specification, the deterministic trend is ignored, but it is included in the second. Diebold and Senhadji (1996) showed that whether these tests detect presence of deterministic or stochastic trend depends on the analyzed time period - the longer the period the higher the chance of encountering a deterministic trend. This implies that for the periods used in this paper, the test is expected to be biased towards the stochastic trend. The presence of the trend was also confirmed with the KPSS (Kwiatkowski et al, 1992) test. Results for specification without deterministic trend for countries have been presented in Table 2. Results for regions at NUTS 1 level are in the appendix. Since the number of observations is very high, (242 for NUTS 2 and 1260 for NUTS 3 ) the results for lower levels of disaggregation are not presented, but they confirm the presence of a trend in the data.

Table 2. Results of unit root test: specification (1) without $\beta \mathrm{t}\left(\mathrm{ADF} \mathrm{H}_{0}\right.$ : series has a unit root; KPSS $\mathrm{H}_{0}$ : series is stationary)

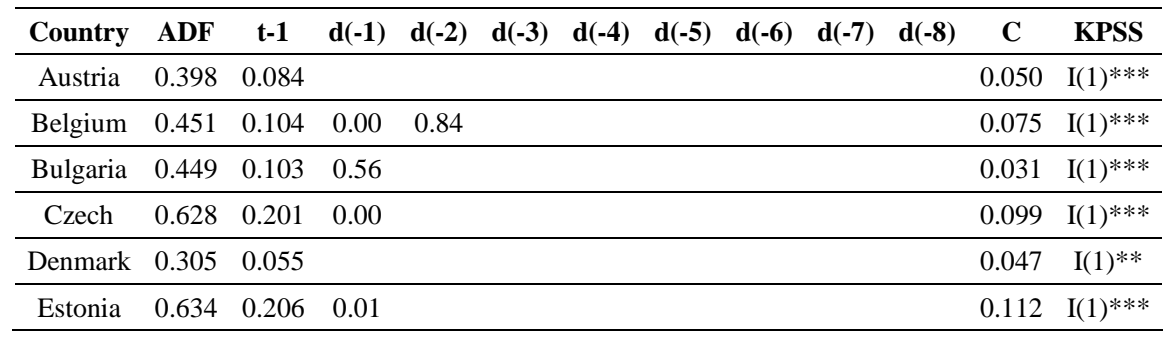

\footnotetext{
${ }^{2}$ The case with no drift is not considered due to the increasing nature of real GDP.
} 
Table 2 continued

\begin{tabular}{|c|c|c|c|c|c|c|c|c|c|c|c|c|}
\hline Country & ADF & $t-1$ & $d(-1)$ & $d(-2)$ & $d(-3)$ & $d(-4)$ & $d(-5)$ & $d(-6)$ & $d(-7)$ & $d(-8)$ & $\mathrm{C}$ & KPSS \\
\hline Finland & 0.277 & 0.048 & 0.07 & & & & & & & & 0.035 & $\mathrm{I}(1)^{* * * *}$ \\
\hline France & 0.219 & 0.034 & 0.01 & & & & & & & & 0.023 & $\mathrm{I}(1)^{* * * *}$ \\
\hline Germany & 0.833 & 0.473 & & & & & & & & & 0.390 & $\mathrm{I}(1)^{* * * *}$ \\
\hline Greece & 0.137 & 0.018 & 0.78 & 0.15 & 0.49 & 0.80 & 0.01 & 0.02 & & & 0.021 & $\mathrm{I}(1)^{*}$ \\
\hline Holland & 0.174 & 0.025 & 0.00 & & & & & & & & 0.020 & $\mathrm{I}(1)^{* * * *}$ \\
\hline Hungary & 0.362 & 0.072 & 0.00 & & & & & & & & 0.052 & $\mathrm{I}(1)^{* * * *}$ \\
\hline Ireland & 0.111 & 0.014 & & & & & & & & & 0.005 & $\mathrm{I}(1) * * *$ \\
\hline Italy & 0.265 & 0.045 & 0.00 & & & & & & & & 0.043 & $\mathrm{I}(1)^{*}$ \\
\hline Latvia & 0.365 & 0.073 & 0.05 & 0.00 & & & & & & & 0.053 & $\mathrm{I}(1)^{* * * *}$ \\
\hline Lithuania & 0.781 & 0.369 & 0.02 & & & & & & & & 0.203 & $\mathrm{I}(1)^{* * * *}$ \\
\hline Poland & 0.996 & 0.317 & & & & & & & & & 0.532 & $\mathrm{I}(1)^{* * * *}$ \\
\hline Portugal & 0.015 & 0.001 & & & & & & & & & 0.001 & $\mathrm{I}(1)^{* * *}$ \\
\hline Romania & 0.651 & 0.219 & 0.44 & & & & & & & & 0.130 & $\mathrm{I}(1)^{* * * *}$ \\
\hline Slovakia & 0.946 & 0.928 & & & & & & & & & 0.393 & $\mathrm{I}(1)^{* * * *}$ \\
\hline Slovenia & 0.395 & 0.083 & 0.15 & 0.01 & & & & & & & 0.064 & $\mathrm{I}(1)^{* * *}$ \\
\hline Spain & 0.069 & 0.008 & 0.00 & & & & & & & & 0.005 & $\mathrm{I}(1)^{* * * *}$ \\
\hline Sweden & 0.769 & 0.354 & 0.29 & 0.00 & 0.18 & 0.00 & 0.22 & 0.42 & 0.02 & 0.00 & 0.197 & $\mathrm{I}(1)^{* * * *}$ \\
\hline UK & 0.358 & 0.071 & & & & & & & & & 0.039 & $\mathrm{I}(1)^{* * * *}$ \\
\hline
\end{tabular}

Table presents $\mathrm{p}$ values for ADF test as well as for all variables.

$* / * * / * * *$ denotes $0.1 / 0.05 / 0.01$ significance level for KPSS statistic

Source: own calculations.

ADF test detects presence of unit root in time series for all countries except Portugal and Spai, two geographically close countries that have experienced significant turmoil during the recent crisis. According to the KPSS test results, unit root is present in all countries. Results for the specification (1) are presented in Table 3.

For specification (1), the ADF test shows the presence of unit root in time series for all countries. KPSS shows presence of unit root in all cases except for Germany. This result, along with the analysis of $\mathrm{p}$ values in both specifications, gives strong support to the deterministic trend only in the case of Germany, though evidence for stochastic trend can be found. Table 3 shows that deterministic trend is significant also for Bulgaria, Estonia, Greece, Poland, Romania and Slovakia. In most of the cases, the results point to a stochastic trend and drift. As mentioned above, this result was expected because of a relatively short time period. This result has consequences for the measurement of business cycle component and final result. 
It points out to changes in trend underlying GDP. This difficulty is addressed and overcome later in the text.

Table 3. Results of unit root test: specification (1) $\left(A D F H_{0}\right.$ : series has a unit root; KPSS $\mathrm{H}_{0}$ : series is stationary)

\begin{tabular}{|c|c|c|c|c|c|c|c|c|c|c|c|c|c|}
\hline Country & ADF & $t-1$ & $d(-1)$ & $d(-2)$ & $d(-3)$ & $d(-4)$ & $d(-5)$ & $d(-6)$ & $d(-7)$ & $d(-8)$ & C & $\mathbf{t}$ & KPSS \\
\hline Austria & 0.598 & 0.052 & & & & & & & & & 0.039 & 0.120 & $\mathrm{I}(1)^{*}$ \\
\hline Belgium & 0.378 & 0.020 & 0.00 & & & & & & & & 0.015 & 0.053 & $\mathrm{I}(1)^{* * *}$ \\
\hline Bulgaria & 0.962 & 0.438 & 0.52 & & & & & & & & 0.220 & 0.761 & $\mathrm{I}(1)^{* * *}$ \\
\hline Czech & 0.947 & 0.359 & 0.00 & & & & & & & & 0.233 & 0.582 & $\mathrm{I}(1)^{* * *}$ \\
\hline Denmark & 0.847 & 0.162 & & & & & & & & & 0.128 & 0.822 & $\mathrm{I}(1)^{* *}$ \\
\hline Estonia & 0.321 & 0.015 & 0.03 & 0.43 & 0.01 & & & & & & 0.009 & 0.054 & $\mathrm{I}(1)^{* * *}$ \\
\hline Finland & 0.871 & 0.188 & 0.07 & & & & & & & & 0.124 & 0.676 & $\mathrm{I}(1)^{* *}$ \\
\hline France & 0.589 & 0.050 & 0.00 & & & & & & & & 0.037 & 0.169 & $\mathrm{I}(1)^{* * *}$ \\
\hline Germany & 0.121 & 0.003 & 0.01 & & & & & & & & 0.003 & 0.005 & $\mathrm{I}(0)$ \\
\hline Greece & 0.999 & 0.556 & & & & & & & & & 0.619 & 0.000 & $\mathrm{I}(1)^{* * * *}$ \\
\hline Holland & 0.938 & 0.325 & 0.00 & & & & & & & & 0.250 & 0.957 & $\mathrm{I}(1)^{* *}$ \\
\hline Hungary & 0.803 & 0.128 & 0.00 & & & & & & & & 0.079 & 0.564 & $\mathrm{I}(1)^{* * * *}$ \\
\hline Ireland & 0.785 & 0.116 & & & & & & & & & 0.037 & 0.768 & $\mathrm{I}(1)^{* * * *}$ \\
\hline Italy & 0.855 & 0.170 & 0.00 & & & & & & & & 0.134 & 0.277 & $\mathrm{I}(1)^{* * * *}$ \\
\hline Latvia & 0.423 & 0.025 & 0.04 & 0.00 & & & & & & & 0.015 & 0.134 & $\mathrm{I}(1)^{* * *}$ \\
\hline Lithuania & 0.804 & 0.129 & 0.01 & & & & & & & & 0.076 & 0.204 & $\mathrm{I}(1)^{* * *}$ \\
\hline Poland & 0.627 & 0.059 & 0.17 & 0.54 & 0.10 & & & & & & 0.037 & 0.058 & $\mathrm{I}(1)^{* * *}$ \\
\hline Portugal & 0.750 & 0.098 & & & & & & & & & 0.060 & 0.105 & $\mathrm{I}(1)^{* * * *}$ \\
\hline Romania & 0.396 & 0.022 & 0.91 & & & & & & & & 0.013 & 0.045 & $\mathrm{I}(1)^{* *}$ \\
\hline Slovakia & 0.701 & 0.080 & & & & & & & & & 0.050 & 0.075 & $\mathrm{I}(1)^{*}$ \\
\hline Slovenia & 0.778 & 0.113 & 0.11 & 0.00 & & & & & & & 0.070 & 0.388 & $\mathrm{I}(1)^{* *}$ \\
\hline Spain & 0.983 & 0.651 & 0.01 & & & & & & & & 0.310 & 0.177 & $\mathrm{I}(1)^{* * * *}$ \\
\hline Sweden & 0.725 & 0.091 & 0.18 & 0.00 & 0.06 & 0.00 & 0.31 & 0.31 & 0.01 & 0.01 & 0.070 & 0.122 & $\mathrm{I}(1)^{*}$ \\
\hline UK & 0.800 & 0.126 & & & & & & & & & 0.078 & 0.416 & $\mathrm{I}(1)^{* * *}$ \\
\hline
\end{tabular}

Table presents $\mathrm{p}$ values for ADF test as well as for all variables.

$* / * * / * * *$ denotes $0.1 / 0.05 / 0.01$ significance level for KPSS statistic

Source: own calculations.

For regions, the KPSS test find unit root for every region at NUTS 1 level. The ADF test fails to find unit root at 5\% level of confidence for 5 regions, namely: Brandenburg, Mecklenburg-Vorpommern, Sachsen, Sachsen-Anhalt (all Germany) and Alföld és Észak (Hungary). These results 
point to the presence of a trend in the analyzed data set, and allows for proceeding with filtering.

In order to extract cyclical and trend components of real GDP time series, high pass Hodrick-Prescott (HP) filter has been used. HP filter assumes that the time series $\left(y_{t}\right)$ can be divided into the cycle component $\left(c_{t}\right)$ and the trend component $\left(g_{t}\right)$ :

$$
y_{t}=c_{t}+g_{t} \quad \text { for } t=1,2, \ldots, T \text {. }
$$

The HP filter extracts the trend component by solving the following mathematical programing problem (Hodrick \& Prescott, 1997):

$$
\begin{gathered}
\min \left\{\sum_{t=1}^{T}\left(y_{t}-g_{t}\right)^{2}+\lambda \sum_{t=1}^{T}\left[\left(g_{t+1}-g_{t}\right)-\left(g_{t}-g_{t-1}\right)\right]^{2}\right\} . \\
\left\{g_{t}\right\}_{t=-1}^{T}
\end{gathered}
$$

In that context, HP filter can be seen as a generalization of the exponential smoothing procedures used analyzed by Brown (1962). If $c_{t}$ and the second differences of $g_{t}$ are normally and independently distributed, HP filter is an optimal filter (Rawn \& Uhlig, 2002). $\lambda$ is a parameter penalizing for variability of the trend component and its value is given by:

$$
\lambda=\frac{\sigma_{c}^{2}}{\sigma_{\Delta^{2}}^{2} g_{t}},
$$

which is the ratio of variance in the cyclical component to variance of the second differences in the trend component. The higher the value of $\lambda$, the smoother the trend component, and it becomes an OLS estimate as $\lambda$ approaches $\infty$. The value has been set to 1600 for quarterly and to 100 to annual data, which are the values recommended by authors, as well as commonly used in the most of business cycles literature (e.g. Backus \& Kehoe, 1992). A great advantage of Hodrick-Prescott filter is the fact that it directly corresponds to the definition of business cycle commonly used in the economic literature as: movements about trend in gross national product (Lucas, 1977). 
Finally, the cyclical component $c_{t}$ is divided by the trend component $g_{t}$, to create a time series of deviations of cyclical part of real GDP from trend part, or in other words deviations of cyclical GDP from the natural level:

$$
\operatorname{dev}_{t}={ }^{c_{t}} / t_{t}
$$

This transformation deals with the problem of stochastic trend, as the cyclical component is scaled by trend component.

For each pair of countries/regions $i$ and $j$, for each level of aggregation separately, the value of the correlation coefficient is calculated for data obtained with HP filter:

$$
h p_{i j}=\operatorname{cor}\left(d e v_{t i}, d e v_{t j}\right)
$$

This measure takes values from -1 to 1 , where 1 reflects perfect business cycle synchronization. Because BCS can be analyzed using at least two countries, the unit used in this research is pairwise oriented. An advantage of this approach is that the number of observations $(o)$ for a given number of countries/regions $(n)$ is given by:

$$
o=\frac{n(n-1)}{2}
$$

so, for 24 countries, the number of observations is276, for 82 NUTS 1 - 3321, for 242 NUTS 2 - 29161, for 1263 NUTS 3 - 796953 observations. In the case of, NUTS 3 one can be sure that all asymptotical theorems work very well. The rest of the reasoning is based on the values of these results.

\section{Results}

The descriptive statistics for values of $h p$ measure for region pairs at NUTS 1, 2 and 3 are presented in Table 4. The headers of columns with „IN' present results only for pairs of regions inside the countries (a Polish region with a Polish region, a German one with a German one, but not a Polish one with a German one). The degree of business cycle synchronization is very high at all three levels of aggregation though the highest is at NUTS 1 level (0.89). The average value of $h p$ is decreasing with disaggregation, which is the expected result. Nevertheless, this very high value for all three levels of disaggregation indicates that the conduction of monetary policy would be on average rather effective, judging from the regional perspec- 
tive. On the other hand, the distribution in all cases is far from normal, which might indicate that there is some systematic factor attributing to skewness. For this reason, statistics were calculated separately for pairs of regions within countries. Mean values within countries are significantly higher - by approximately 0,1 for NUTS 1 and NUTS 2 and 0,08 NUTS region pairs. Standard deviation for 'inside' pairs is on the other hand significantly lower, approximately by factor of 12, 4 and 2.1 for NUTS 1,2 and 3 region pairs respectively.

Figure 1. Kernel Densities for NUTS 1, 2 and 3 region pairs: all and within countries

NUTS 1
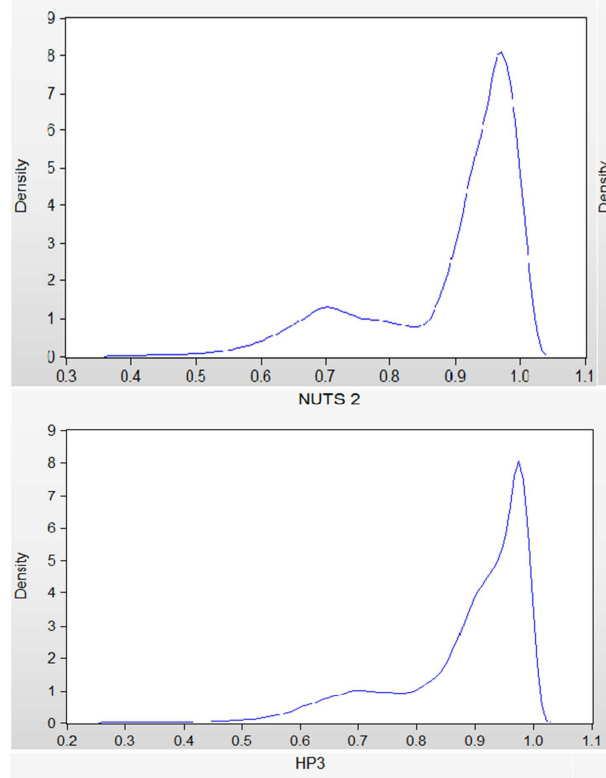

NUTS 1 within countries

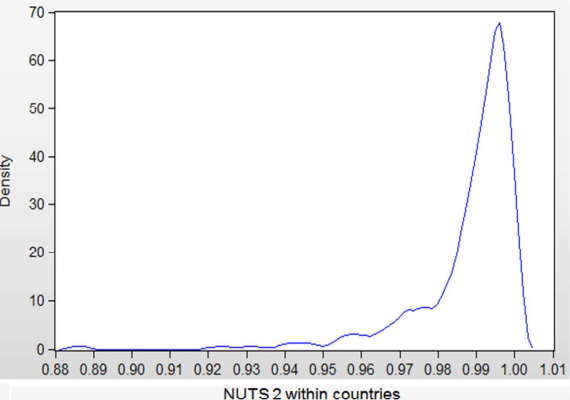

NUTS 2 within countries

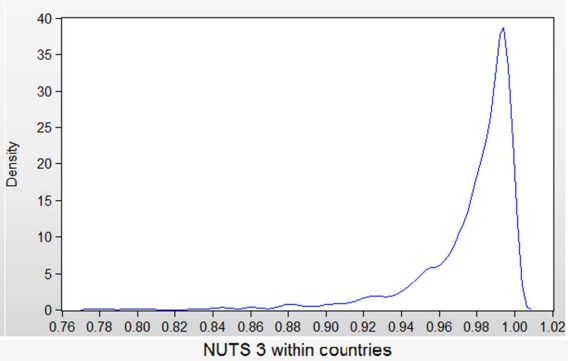

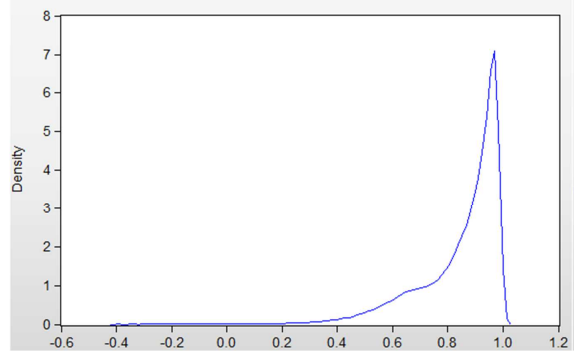

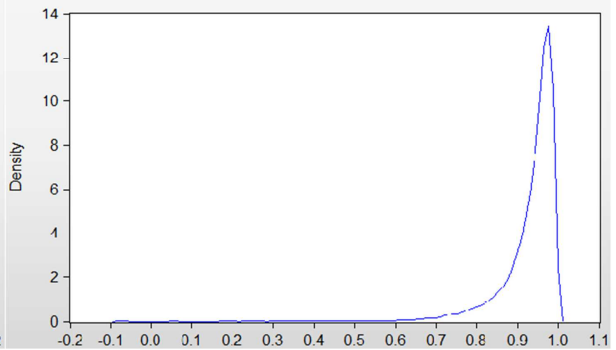

Source: own calculation. 
Conclusions from Table 4 are supported by comparison of the distribution between all pairs of regions and pairs within counters. Kernel densities for region pairs are presented in Figure 1.

Table 4. Descriptive statistics of $h p$ for NUTS 1,2 and 3 region pairs: all and within countries*

\begin{tabular}{ccccccc}
\hline Statistic & NUTS1 & NUTS1IN & NUTS2 & NUTS2IN & NUTS3 & NUTS3IN \\
\hline Mean & 0.89 & 0.99 & 0.88 & 0.98 & 0.85 & 0.93 \\
\hline Median & 0.94 & 0.99 & 0.92 & 0.99 & 0.90 & 0.95 \\
\hline Maximum & $1.00 * *$ & 1.00 & 1.00 & 1.00 & 1.00 & 1.00 \\
\hline Minimum & 0.40 & 0.89 & 0.29 & 0.78 & -0.39 & -0.08 \\
\hline Std. Dev. & 0.12 & 0.01 & 0.12 & 0.03 & 0.15 & 0.07 \\
\hline Skewness & -1.38 & -3.03 & -1.40 & -2.45 & -1.60 & -2.59 \\
\hline Kurtosis & 3.96 & 16.86 & 4.40 & 11.17 & 5.80 & 13.76 \\
\hline Jarque-Bera & 1178 & 2784 & 11866 & 7992 & 602586 & 703580 \\
\hline P(J-B) & 0.00 & 0.00 & 0.00 & 0.00 & 0.00 & 0.00 \\
\hline Sum & 2962 & 289 & 25681 & 2064 & 675351 & 110500 \\
\hline Sum Sq. Dev. & 44.57 & 0.05 & 392.55 & 1.35 & 16873.30 & 515.73 \\
\hline Observations & 3321 & 292 & 29161 & 2112 & 795691 & 118449 \\
\hline
\end{tabular}

*ENDFIX "IN" denotes correlations within countries

**Values of correlations equal to 1 are results of rounding up

Source: own calculation.

The distributions for all and inside pairs are not normal and get more concentrated around mean with the level of aggregation, which can be attributed to the sample size changes. The distribution for 'inside' pairs is more concentered and only covers very high values of correlation coefficient. These results suggest that the business cycle of regions inside countries are on average more synchronized than those of regions from different countries. This result contradicts 'Krugman's View' which states that the elimination of barriers to all economic activities (ex. Trade, mobility of labor and capital) leads to higher degree of concentration of economic activity due to internal and external economies of scale. This, in turn, leads to higher specialization, fragility of regions exports to changes in demand, and lower business cycles synchronization with other regions. The obtained result shows that regions are characterized by a very high degree of business cycle synchronization, especially within countries. This also supports the 'European Commission View'. Further economic integration by eliminating barriers to economic activity and introducing similar policies - ergo 
making groups of countries more like one country - will lead to tighter business cycle synchronization and can make common monetary policy effective.

The results for regions are very different from pairs of countries, which are presented in Table 5.

Table 5. Descriptive statistics of $h p$ for pairs of countries and NUTS 3 level pairs within Poland, Germany, France and UK*

\begin{tabular}{cccccc}
\hline Statistic & COUNTRIES & POLAND & GERMANY & FRANCE & UK \\
\hline Mean & 0.65 & 0.92 & 0.93 & 0.99 & 0.88 \\
\hline Median & 0.71 & 0.94 & 0.95 & 0.99 & 0.90 \\
\hline Maximum & 0.95 & 1.00 & 1.00 & 1.00 & 1.00 \\
\hline Minimum & 0.11 & 0.47 & 0.25 & 0.94 & 0.18 \\
\hline Std. Dev. & 0.21 & 0.07 & 0.06 & 0.01 & 0.08 \\
\hline Skewness & -0.80 & -2.58 & -2.38 & -2.04 & -1.94 \\
\hline Kurtosis & 2.61 & 11.23 & 10.97 & 9.77 & 8.67 \\
\hline Jarque-Bera & 31 & 8424 & 327137 & 11875 & 16490 \\
\hline P(J-B) & 0.00 & 0.00 & 0.00 & 0.00 & 0.00 \\
\hline Sum & 180 & 1975 & 84843 & 4517 & 7377 \\
\hline Sum Sq. Dev. & 11.71 & 10.09 & 332.78 & 0.23 & 60.11 \\
\hline Observations & 276 & 2145 & 90951 & 4560 & 8385 \\
\hline
\end{tabular}

*For brevity data for only 5 countries is reported. All results are available upon request

Source: own calculation.

The mean value of correlation coefficient for country pairs is equal 0.65 , which is lower by 0.3 from NUTS 3 region pairs. Standard deviation is equal to 0.21 , which, in turn, indicates a lower concentration of the results. The distribution is not normal, which can be seen from kernel densities in Figure 2. The distribution almost exclusively covers values from 0 to 1 . This suggests that, in total, business cycle synchronization among European countries is fairly strong, but the degree differs significantly between pairs. The highest density of observations is around 0.75 which strengthens the point. 
Figure 2. Kernel Densities for country pairs and pairs of regions at NUTS 3 level inside: Poland, Germany, France and UK

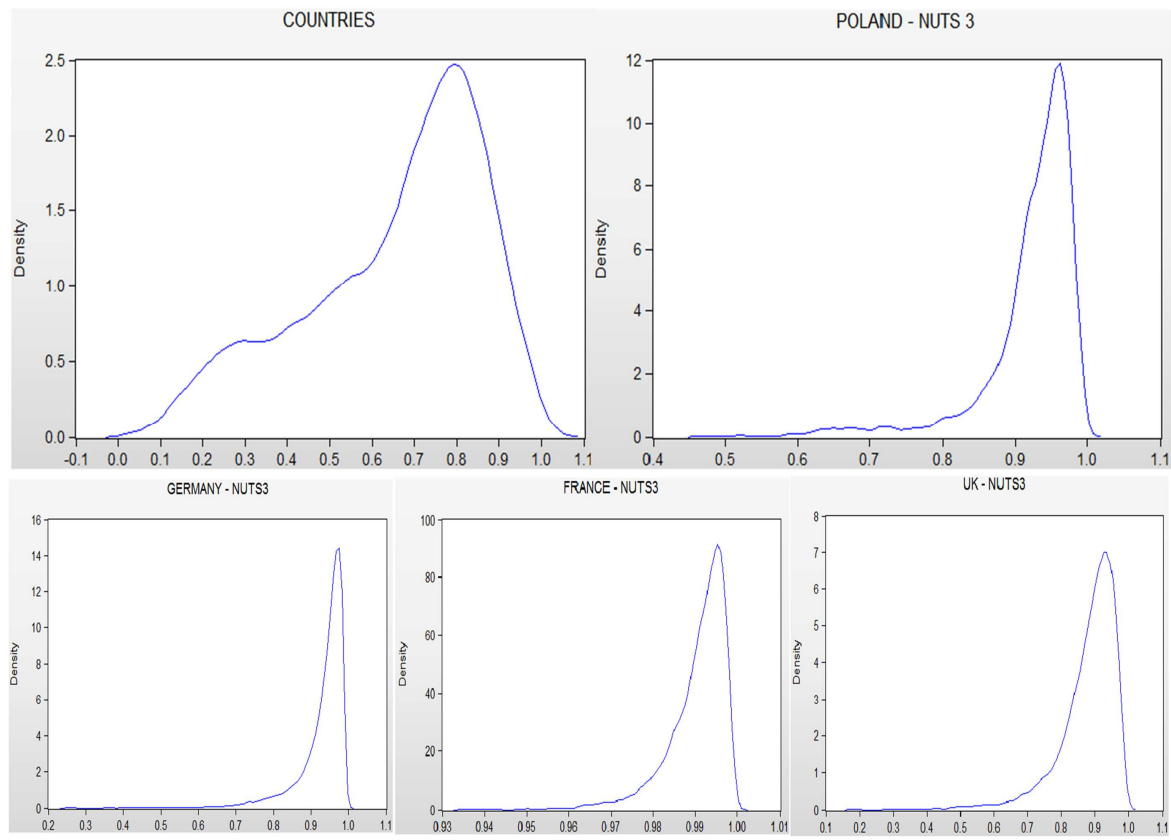

Source: own calculation.

Table 5 also displays descriptive statistics for NUTS 3 region pairs inside Poland, Germany, France and UK. Results for these countries confirm that, in all cases, monetary policy can be implemented very effectively. This is especially true in the case of France, where the mean value of $h p$ measure is equal to 0.99 with standard deviation equal to approximately 0.01 . The degree of business cycle synchronization is also very high for Poland, with the mean of 0.92 and standard deviation of 0.07 . The distribution in all cases is not normal, which can be seen in Figure 2. Kernel distributions for regions inside countries are very concentrated and only cover very high values of correlation.

The results of the detailed analysis are presented in Tables 6 trough 9 . For each country, possible partners for monetary union are arranged according to $h p$ measure in a descending order. NUTS $1 / 2 / 3$ denotes the average value for region pairs inside this country at a different $1 / 2 / 3$ level of aggregation, while mean denotes the average value in all countries. If the country has higher business cycle synchronization with some other country than among regions inside it, then this country is a good partner to form 


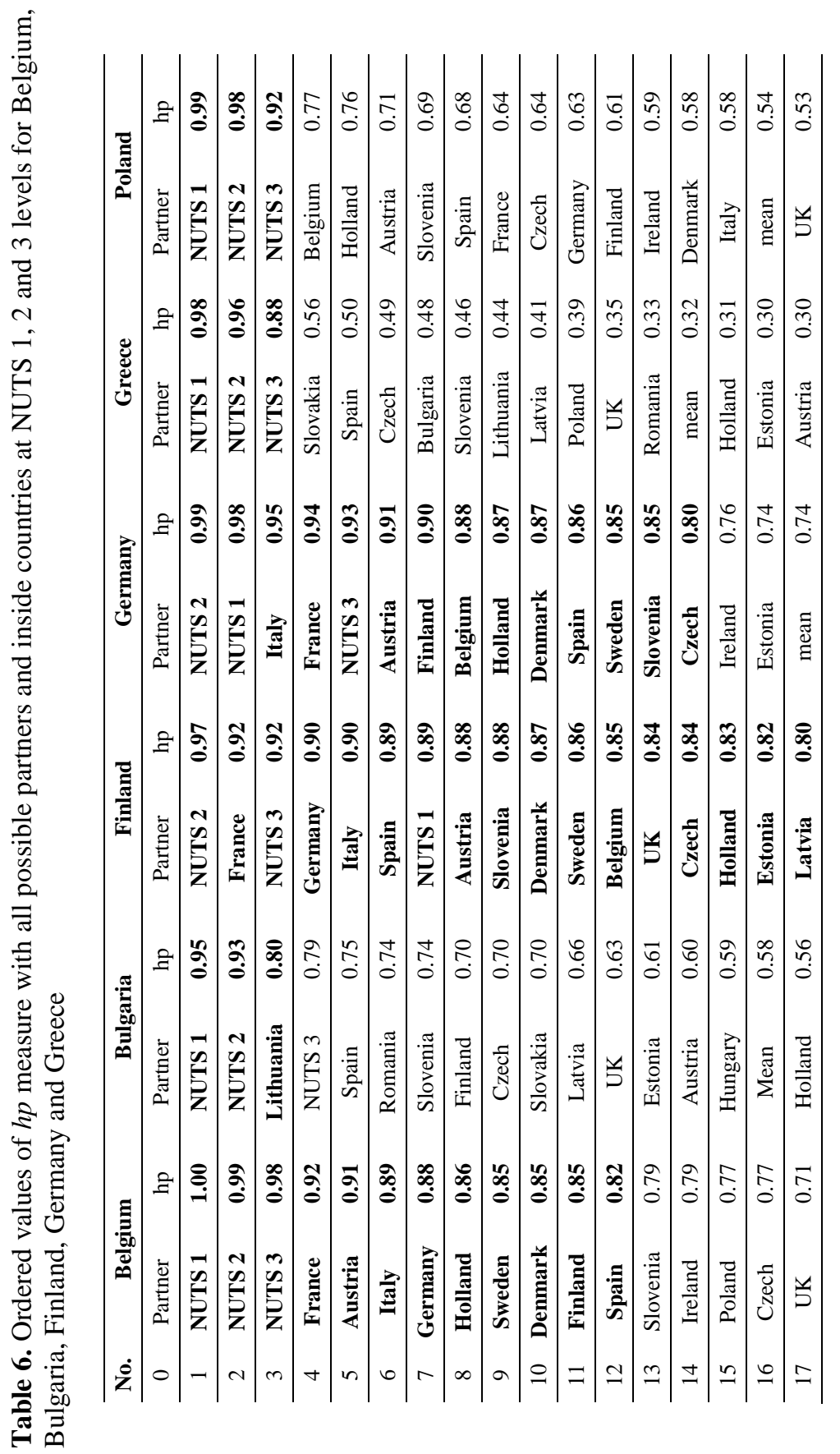




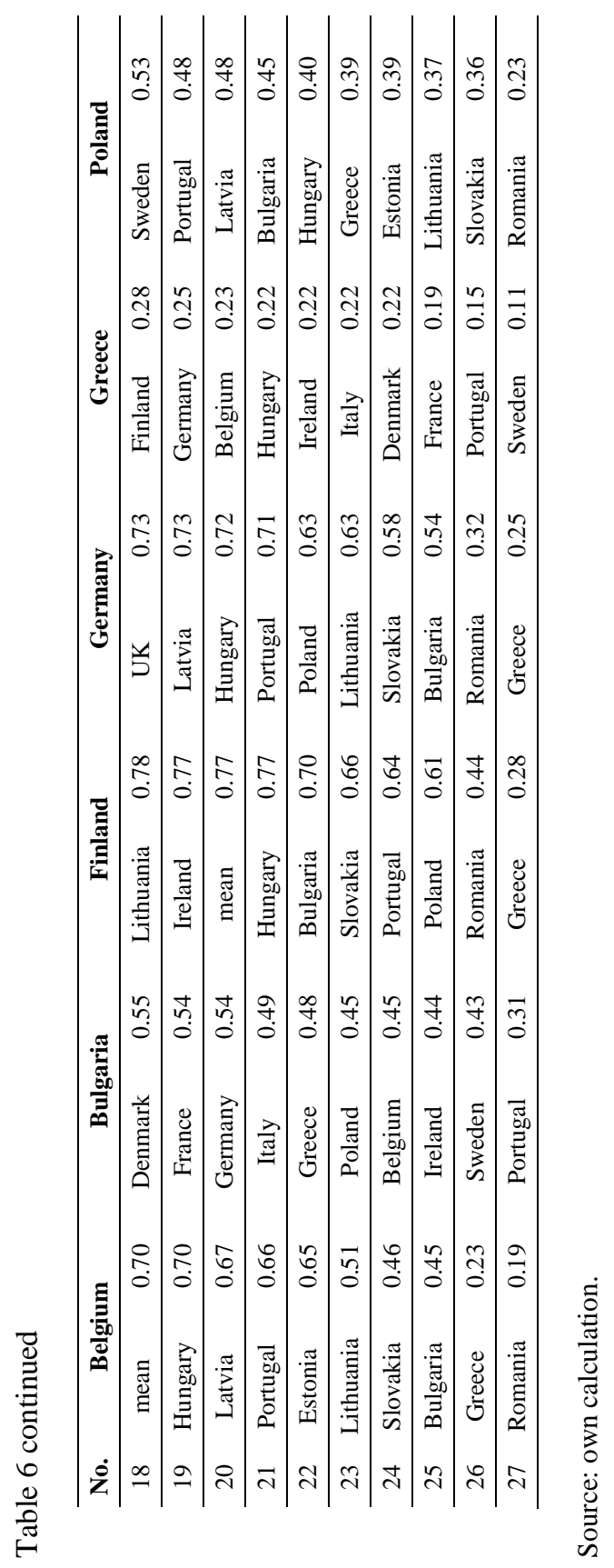




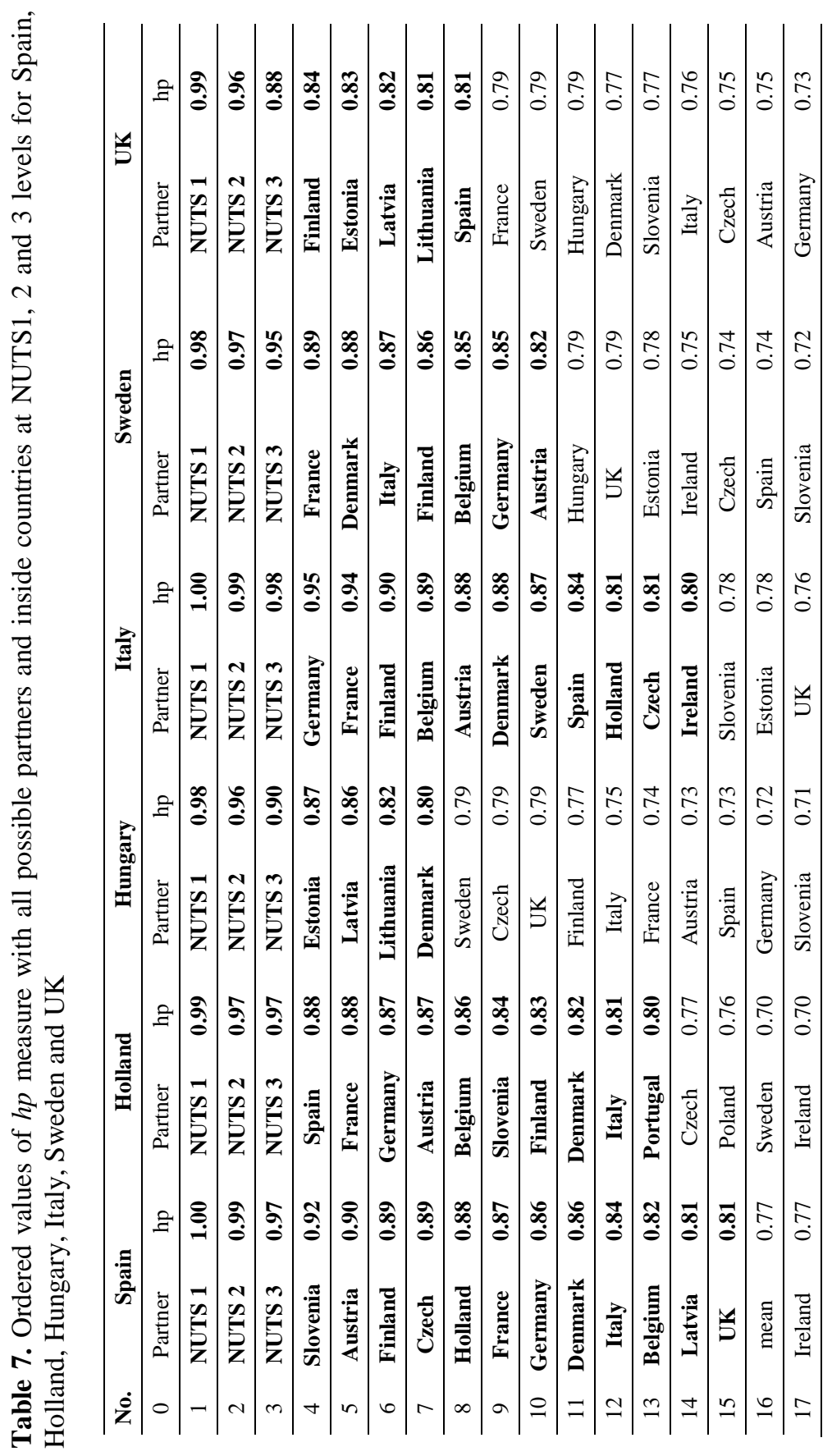




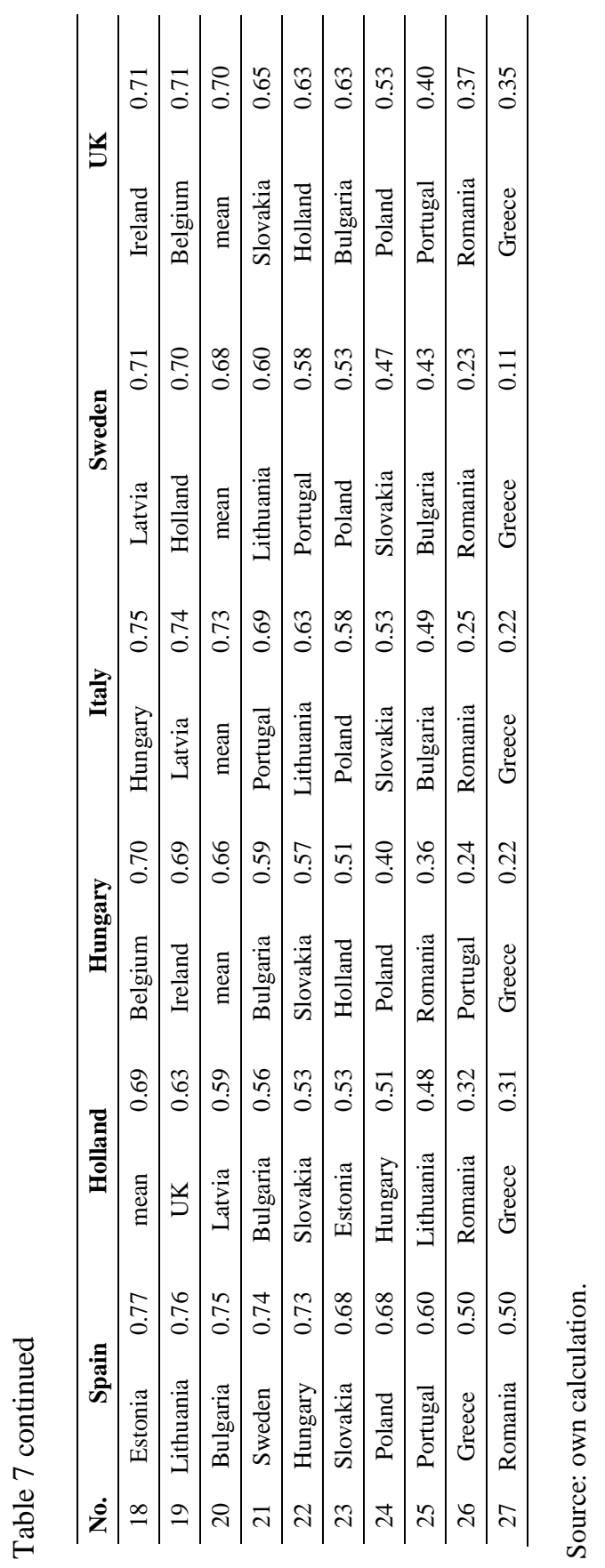




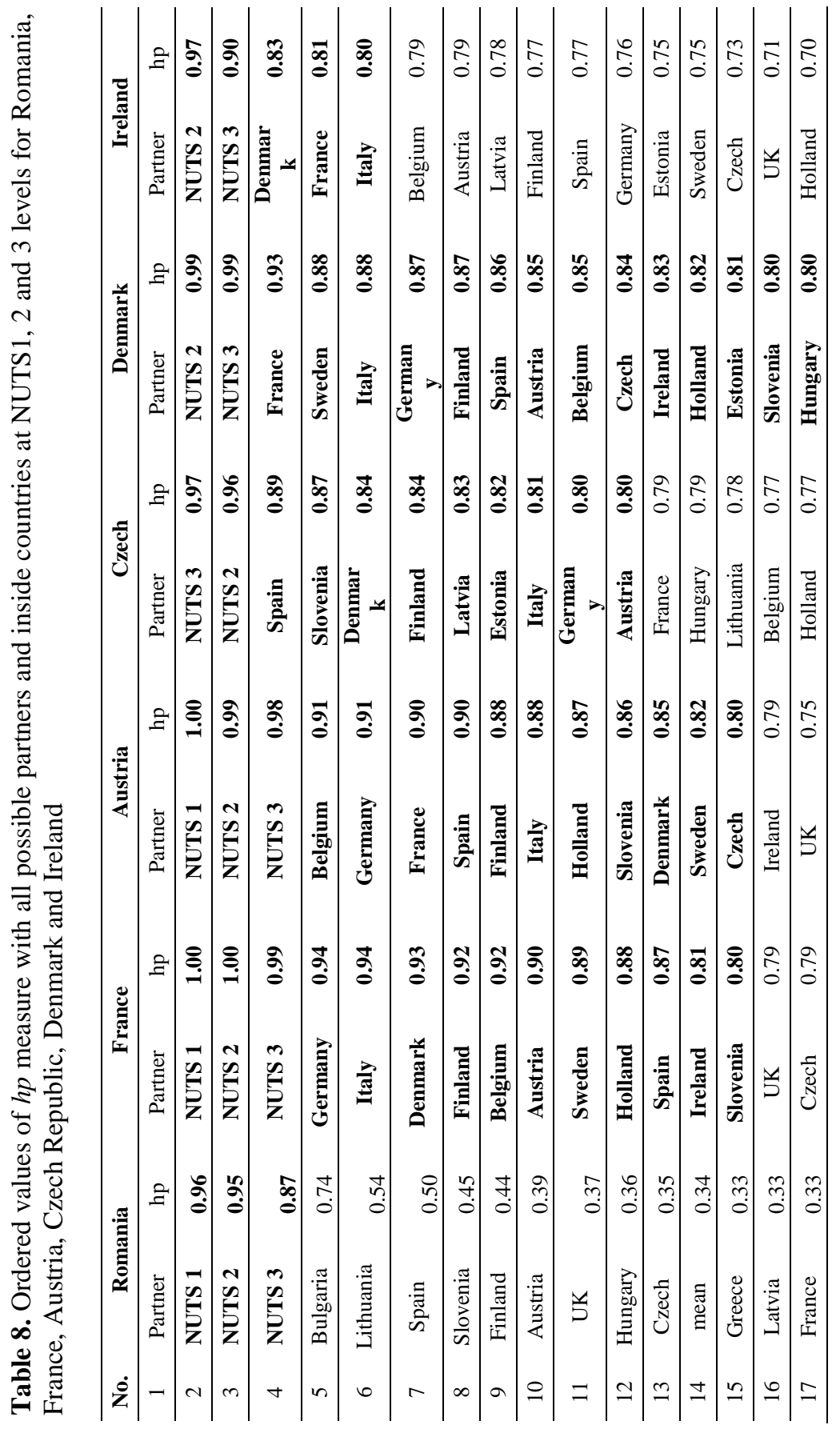




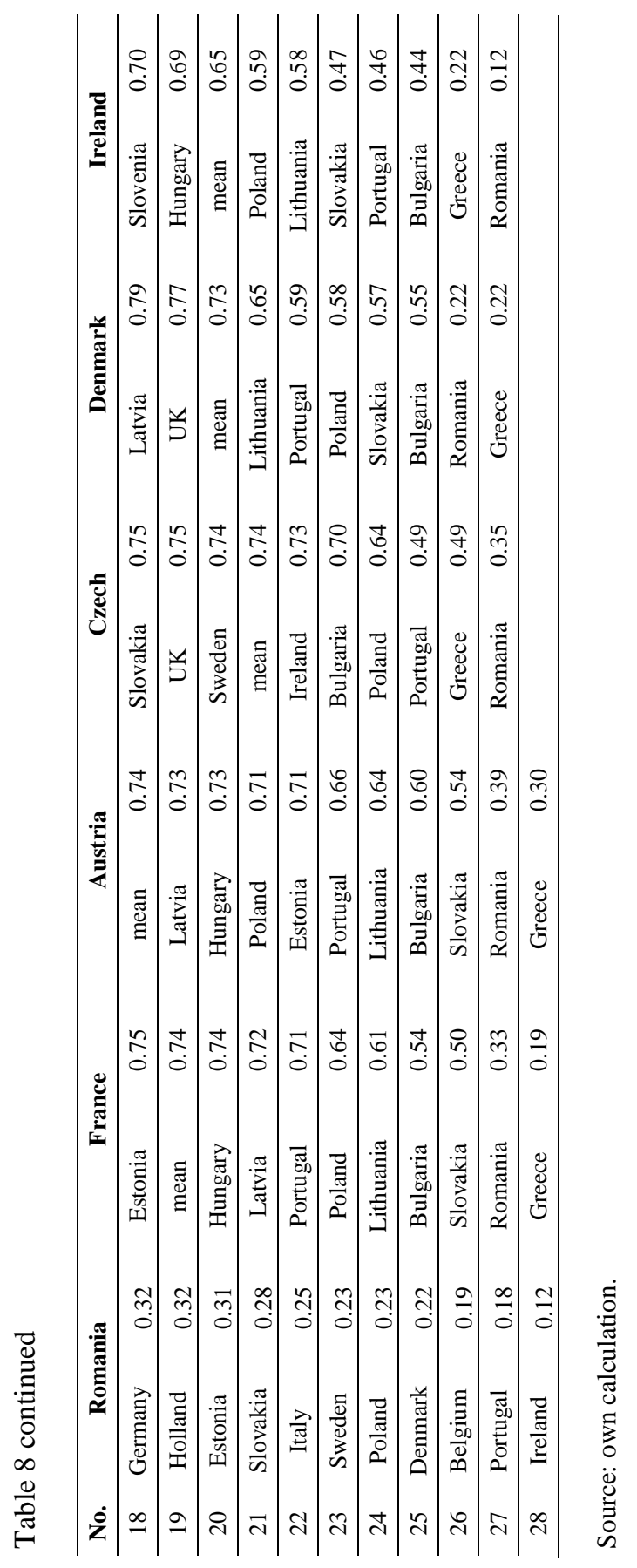




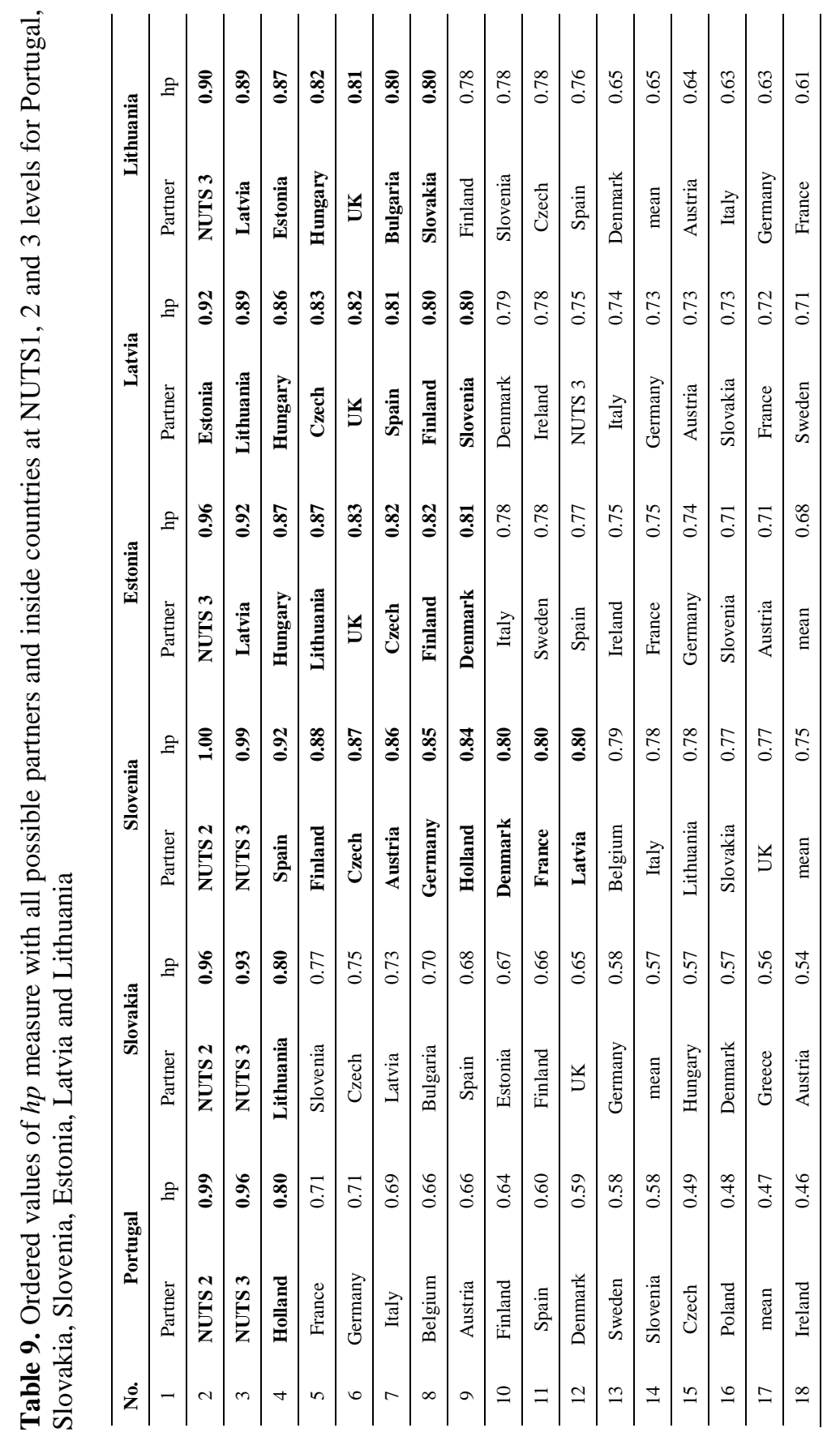




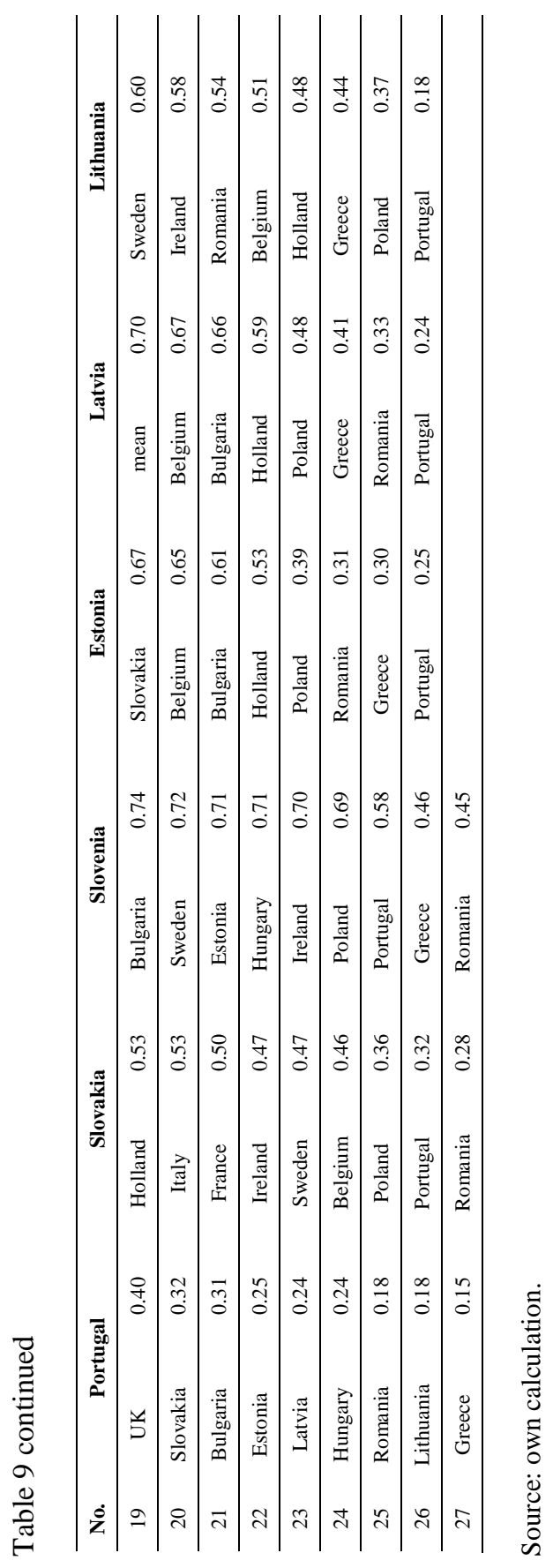


a monetary union with. In other words, monetary policy could be implemented in these two countries, as effectively as for regions of one country - the costs of participation in monetary union do not apply. This criterion is extremely rigorous and has not been met in many cases.

The values of correlation coefficient for NUTS 1,2 and 3 level region pairs is higher than with any other country in the case of Belgium, Greece, Poland, Spain, Holland, Hungary, Sweden, UK, Romania, France, Austria, the Czech Republic, Denmark, Ireland, Portugal, Slovakia, Slovenia, Estonia and Lithuania. Bulgaria has hp value for NUTS 3 'inside' equal to 0.79 , while with Lithuania -0.8 , so this country is a suitable candidate for monetary union with Bulgaria. Germany has higher value of hp with Italy and France than for region pairs at NUTS 3 level of aggregation (0.93). Latvia is characterized by a very low value of correlation coefficient for pairs of NUTS 3 regions within countries (0.75), in comparison with other countries. This indicates that, from a regional perspective, monetary policy cannot be implemented very effectively (especially in comparison with other countries). Values of hp for Latvia with Estonia, Lithuania, Hungary, Czech Republic, UK, Spain, Finland, Slovenia, Denmark, Ireland (in descending order) are higher than for within country NUTS 3 level region pairs. This means that the possible number of candidates for monetary union with Latvia is quite extensive. In case of Finland, hp with France is higher than for inside regions at NUTS 3 level inside countries (0.92), and with Germany, Italy and Spain is higher for than for NUTS 1 level regions. This indicates four very favorable candidates to form monetary union with Finland.

Even though there are possible partners for monetary union in case of Bulgaria, Germany, Latvia and Finland, none of them are conceding - there is not even one pair of countries that could form monetary union at virtually no loss in monetary policy effectiveness. But the criterion used here was extremely rigorous, especially if one takes a closer look at values of hp, one can see that they are very high in many cases. Values of hp measure above 0.8 were denoted in bold.

The chosen value of 0.8 is somehow arbitrary but it expresses a rather high degree of business cycle synchronization. Taking this value as a point of reference, Poland does not find any suitable partners with which to form a monetary union. The highest value of hp is observed with Belgium and its equal to 0.77. A similar situation can be seen in the instance of Greece, which has the worst results among all examined countries. In other words, the Greek business cycle is very poorly synchronized with cycles all of analyzed countries - monetary policy that is optimal for any of these countries would be inappropriate for Greece. 
Using 0.8 as a reference value, some countries have considerable numbers of possible candidates for introduction of a common currency: Belgium (9 countries), Finland (14), Germany (11), Spain (12), Holland (10), Italy (11), France (12), Austria (12), Denmark (15) and Slovenia (10). Numbers for other countries are not as big, but still multiple pairs of countries with highly synchronized business cycles can be found. This also indicates that a lot of countries from the Euro Area form an organism that can be considered quite close to an optimum currency area. Germany, France, Italy, Austria, Belgium, Holland, Spain, Austria and Finland constitute such an entity - an optimal monetary policy for one of these countries is very close to optimal policies for all others. Unfortunately, the same thing cannot be said about other members of Euro Area with Greece being a leading outlier.

\section{Conclusions}

The extraction of the cyclical components with Hodrick-Prescott filter from real GDP time series in order to obtain the correlation coefficient of deviations of cyclical component from trend resulted in obtaining 276 measures for country pairs, as well as 3321, 29191 and 796953 measures for NUTS 1,2 and 3 level region pairs respectively. The analysis revealed that the average value of $h p$ measure for countries and NUTS 1,2 and 3 regions are equal to $0.65,0.89,0.88$ and 0.85 respectively. This shows that business cycle synchronization at regional level is generally higher than at country level, but is mostly driven by high degree of business cycle synchronization among regions within countries. This result contradicts 'Krugman's View' which states that the elimination of barriers to all economic activities leads to a higher degree of concentration of economic activity due to economies of scale. These, in turn, would lead to higher specialization, fragility of regions exports to changes in demand and lower business cycles synchronization with other regions. To the contrary, it gives support to 'European Commission View'. Further economic integration by eliminating barriers to economic activity and introducing similar policies - ergo making groups of countries more like one country - will lead to tighter business cycle synchronization and can make common monetary policy effective.

Very restrictive criterion that used comparisons of business cycle synchronization at regional level within countries with country level correlations was used to assess whether two countries can enter a monetary union with each other with virtually no cost of monetary policy effectiveness loss. This restrictive criterion showed that four countries have candidates for 
effective monetary union formation, namely: Bulgaria, Finland, Germany and Latvia. On the other hand, requirement must be fulfilled for two countries - and that criterion was not met. Using a less restrictive criterion of correlation coefficient equal to 0.8 , it turned out that many countries have many good candidates with which to introduce a common currency. For example: Belgium (9 countries), Finland (14), Germany (11), Spain (12), Holland (10), Italy (11), France (12), Austria (12), Denmark (15) and Slovenia (10). Numbers for other countries are lower, but still many pairs of countries with highly synchronized business cycles can be found. This also indicates that a lot of countries from the Euro Area form an organism that can be considered quite close to optimum currency area. Germany, France, Italy, Austria, Belgium, Holland, Spain, Austria and Finland constitute such an entity - optimal monetary policy for one of these countries is very close to optimal policies for all others. Unfortunately, the same thing cannot be said about other members of Euro Area with Greece being a leading outlier.

The results also show that the Polish National Bank can use monetary policy very effectively, no matter what regional level of aggregation is used as reference point. On the other hand, the values of business cycle synchronization for Poland and other countries are very low. This indicates that there are no good candidates to form a monetary union with Poland. Poland is additionally the second outlier, after Greece, within the analyzed group. This result should not be worrying as a low degree of business cycle synchronization with other European countries can be attributed to a good economic performance of Poland during the recent crisis.

\section{References}

Anagnostou, A., Panteladis, I., \& Tsiapa, M. (2012). Disentangling Different Patterns of Business Cycle Synchronicity in The EU Regions. In ERSA Conference Papers. DOI: http://dx.doi.org/10.1007/s10663-014-9268-9.

Alesina, A., \& Barro, R. (2002). Currency Unions. Quarterly Journal of Economics, 117(2). DOI: http://dx.doi.org/10.1162/003355302753650283.

Artis, M., Dreger, C., \& Kholodilin, K. (2011). What Drives Regional Business Cycles? The Role of Common and Spatial Components. ERSA Conference Papers. DOI: http://dx.doi.org/10.1111/j.1467-9957.2010.0 2214.x.

Backus, D., \& Kehoe, P. (1992). International Evidence of the Historical Properties of Business Cycles. American Economic Review, 82(4).

Baxter, M., \& Kouparitsas, M. (2005). Determinants of Business Cycle Comovement: a Robust Analysis. Journal of Monetary Economics, 52(1). DOI: http://dx.doi.org/10.1016/j.jmoneco.2004.08.002. 
Bayoumi, T., \& Eichengreen, B. (1993). Shocking Aspects of European Monetary Integration. In F. Torres \& F. Giavazzi (Eds.). Adjustment and Growth in the European Monetary Union. Cambridge University Press. DOI: http://dx.doi. org/10.1017/CBO9780511599231.014.

Bayoumi, T., \& Eicheengreen, B. (1997). Ever Closer to Heaven? An Optimumcurrency-area Index for European Countries. European Economic Review, 41(3-5). DOI: http://dx.doi.org/10.1016/S0014-2921(97) 00035-4.

Beck, K. (2013). Structural Similarity as a Determinant of Business Cycles Synchronization in the European Union: a Robust Analysis. Research in Economics and Business: Central and Eastern Europe, 5(2).

Beck, K. (2014). Determinanty synchronizacji cykli koniunkturalnych w krajach Unii Europejskiej w latach 1990-2007. Gospodarka w Teorii i Praktyce, 1(34).

Beck, K., \& Janus, J. (2013). Aggregate Demand Disturbances in the Visegrad Group and the Eurozone. Entrepreneurial Business and Economics Review, 1(3). DOI: http://dx.doi.org/10.15678/EBER.2013.010302.

Beck, K., \& Janus, J. (2014). Synchronization of Economic Shocks in The Visegrad Group: An Empirical Assessment. Studia Ubb Negotia, 49(2).

Blanchard, O., \& Quah, D. (1989). The Dynamic Effects of Aggregate Supply and Demand Disturbances. American Economic Review, 79(4).

Bordo, M., \& Helbling, T. (2011). International Business Cycle Synchronization In Historical Perspective. NBER Working Papers, 16103. DOI: http://dx.doi.org/ 10.1111/j.1467-9957.2010.02236.x.

Böwer, U., \& Guillemineau, C. (2006). Determinants of Business Cycles Synchronization Across Euro Area Countries. ECB Working Papers, 587.

Correia, L., \& Gouveia, S. (2013). Business Cycle Synchronisation at the Regional Level: Evidence for the Portuguese Regions. Regional and Sectoral Economic Studies, 13(1).

Chang, K., Kim, Y., Tomljanovich, M., \& Ying, Y. (2013). Do Political Parties Foster Business Cycle? An Examination of Developed Economies. Journal of Comparative Economics, 41(1). DOI: http://dx.doi.org/10.1016/j.jce.2012.04 .005 .

Diebold, F., \& Senhadji, A. (1996). Deterministic vs. Stochastic Trend in U.S. GNP, Yet Again. NBER Working Papers, 5481.

Dumitru, I., \& Dumitru I. (2011). Similarity of Supply and Demand Shocks between the New Member States and the Euro Zone. The case of Romania. Romanian Journal of Economic Forecasting, 1(1).

Frankel, J., \& Rose, A. (1998). The Endogeneity of the Optimum Currency Area Criteria. Economic Journal, 108(449). DOI: http://dx.doi.org/10.1111/14680297.00327.

Gogas, P. (2013). Business Cycle Synchronization in the European Union: The Effect of the Common Currency. The Rimini Centre for Economic Analysis, Working Paper Series, 18(13).

Imbs, J. (2004). Trade, Finance, Specialization, and Synchronization. Review of Economics and Statistics, 86(3). DOI: http://dx.doi.org/10.1162/00346 $\underline{53041811707 .}$ 
Kalemli-Ozcan, S., Papaioannou, E., \& Peydró, J. (2009). Financial Integration and Business Cycles Synchronization. Working Paper.

Kenen, P. (1969). The Theory of Optimum Currency Areas: An Eclectic View. In T. Mundell \& A. Swoboda (Eds.). Monetary Problems in the International Economy. University of Chicago Press.

Krugman, P. (1993). Lessons of Massachusetts for EMU. In F. Torres \& F. Giavazzi (Eds.). Adjustment and Growth in the European Monetary Union. Cambridge University Press. DOI: http://dx.doi.org/10.1017/CBO97805115 99231.016.

Kwiatkowski, D., Phillips, P., Schmidt, P., \& Shin, Y. (1992). Testing the Null Hypothesis of Stationarity against the Alternative of a Unit Root. Journal of Econometrics, 54(1-3). DOI: http://dx.doi.org/10.1016/0304-4076(92)90104-Y.

Leamer, E., \& Leonard, H. (1981). Reporting the Fragility of Regression Estimates. Review of Economics and Statistics, 65(2). DOI: http://dx.doi.org/10 $.2307 / 1924497$.

Leamer, E. (1983). Let's Take the Con out of Econometrics. American Economic Review, 73(1).

Leamer, E. (1985). Sensitivity Analyses Would Help. American Economic Review, 75(3).

Lehwald, S. (2013). Has the Euro Changed Business Cycle Synchronization? Evidence from the Core and the Periphery. Empirica, 4(4). DOI: http://dx.doi.org/ 10.1007/s10663-012-9205-8.

Levine, R., \& Renelt, D. (1992). A Sensitivity Analysis of Cross-Country Growth Regressions. American Economic Review, 82(4).

Lis, S. (2008). Akcesja Polski do strefy euro - analiza krytyczna. Ekonomista, 3.

Lucas, R. (1977). Understanding Business Cycles. In K. Brunner \& A. Meltzer (Eds.). Stabilization of the domestic and international economy, CarnegieRochester Conference Series on Public Policy. DOI: http://dx.doi.org/10.1016/ 0167-2231(77)90002-1.

Łon, E. (2007). Dlaczego Polska nie powinna wchodzić do strefy euro?. Retrieved form www.nbp.pl/publikacje/o-euro (30.09.2009).

Marino, F. (2013). Business Cycle Synchronization across Regions in the EU12: a Structural-Dynamic Factor Approach. mimeo.

McKinnon, R. (1963). Optimum Currency Areas. American Economic Review, 53(1).

Mongelli, F. (2002). "New" Views on the Optimum Currency Area Theory: What is EMU Telling Us?. European Central Bank Working Papers, 138.

Mongelli, F. (2008). European Economic and Monetary Integration and the Optimum Currency Area Theory. European Economy, Economic Papers, 302.

Mundell, R. (1961). A Theory of Optimum Currency Areas. American Economic Review, 51(1).

Mundell, R. (1973a). Uncommon Arguments for Common Currencies. In H. Johnson \& A. Swoboda (Eds.). The Economics of Common Currencies. Allen and Unwin. 
Mundell, R. (1973b). A Plan for a European Currency. In H. Johnson \& A. Swoboda (Eds.). The Economics of Common Currencies. Allen and Unwin.

Nelson, C., \& Plosser, C. (1982). Trends and Random Walks in Macroeconomic Time Series: Some Evidence and Implications. Journal of Monetary Economics, 10.

Nées, S., \& Zorell, N. (2011). Business Cycle Synchronization. Disentangling Trade and Financial Linkages. EBC Working Paper, 1322.

Nowak, A., Żyć, K., \& Żyżyński, J. (1999). Potencjalne skutki wprowadzenia euro dla Polski. Studia Europejskie, 1.

Osiatyński, J. (2011). Warunki gotowości Polski do wejścia do strefy euro. Ekonomista, 5.

Rudebusch, G. (1993). The Uncertain Unit Root in Real GNP. American Economic Review, 83(1).

Ravn, M. O., \& Uhlig, H. (2002). On Adjusting the Hodrick-Prescott Filter for the Frequency of Observations. Review of Economics and Statistics, 84(2). DOI: http://dx.doi.org/10.1162/003465302317411604.

Sachs, J., \& Sala-I-Martin, X. (1991). Fiscal Federalism and Optimum Currency Areas: Evidence for Europe from the United States. NBER Working Paper, 3855.

Said, E., \& Dickey, D. (1984). Testing for Unit Roots in Autoregressive Moving Average Models of Unknown Order. Biometrika, 71(3). DOI: http://dx.doi.org/ $10.2307 / 2336570$.

Sala-I-Martin, X. (1997a). I Just Ran Two Million Regressions. American Economic Review, 27(2).

Sala-i-Martin, X. (1997b). I Just Ran Four Million Regressions. NBER Working Papers, 6252.

Siedschlag, I. (2010). Patterns and Determinants of Business Cycles Synchronization in Enlarged European and Monetary Union. Eastern Journal of European Studies, 1(1).

Tavlas, G. (1993). The 'New' Theory of Optimum Currency Areas. World Economy, 16(6).

Tavlas, G. (2009). The Benefits and Costs of Monetary Union in Southern Africa: a Critical Survey of the Literature. Journal of Economic Surveys, 23(1). DOI: http://dx.doi.org/10.1111/j.1467-6419.2008.00555.x.

Taylor, M. P. (2004). Estimating Structural Macroeconomic Shocks through Longrun Recursive Restrictions on Vector Autoregressive Models: the Problem of Identification. International Journal of Finance and Economics, 9(3). DOI: http://dx.doi.org/10.1002/ijfe.247.

Żyżyński, J., (2009). Wejście do strefy euro-od iluzji do konkretów. Ekonomista, 5.

Żyżyński, J. (2011). Układ interesów dotyczących przejścia na euro. In S. Lis (Ed.). Kontrowersje wokót akcesji Polski do Unii Gospodarczej i Walutowej. Kraków: Wydawnictwo Uniwersytetu Ekonomicznego w Krakowie. 


\section{APPENDIX}

Table A1. ADF and KPSS result for NUTS 1 region real GDP time series

\begin{tabular}{|c|c|c|c|c|c|c|c|}
\hline Country & Region name & ADF & KPSS & Country & Region name & ADF & KPSS \\
\hline Belgium & $\begin{array}{l}\text { Région de Brux- } \\
\text { elles-Capitale }\end{array}$ & 0,939 & $\mathrm{I}(1)^{* *}$ & Italy & Nord Est & 0,332 & $\mathrm{I}(1) * *$ \\
\hline Belgium & Vlaams Gewest & 0,854 & $\mathrm{I}(1)^{* *}$ & Italy & Centro (IT) & 0,699 & $\mathrm{I}(1) * *$ \\
\hline Belgium & Région Wallonne & 0,934 & $\mathrm{I}(1)^{* *}$ & Italy & Sud (IT) & 0,598 & $\mathrm{I}(1)^{* *}$ \\
\hline Bulgaria & $\begin{array}{c}\text { Severna and } \\
\text { iztochna Bulgaria }\end{array}$ & 0,953 & $\mathrm{I}(1)^{* *}$ & Italy & Isole (IT) & 0,675 & $\mathrm{I}(1) * *$ \\
\hline Bulgaria & $\begin{array}{c}\text { Yugozapadna and } \\
\text { yuzhna central } \\
\text { Bulgaria }\end{array}$ & 0,996 & $\mathrm{I}(1)^{* *}$ & Hungary & $\begin{array}{c}\text { Közép- } \\
\text { Magyarország }\end{array}$ & 0,952 & $\mathrm{I}(1) * *$ \\
\hline Germany & $\begin{array}{c}\text { Baden- } \\
\text { Württemberg } \\
\end{array}$ & 0,811 & $\mathrm{I}(1)^{* *}$ & Hungary & Dunántúl & 0,723 & $\mathrm{I}(1) * *$ \\
\hline Germany & Bayern & 0,880 & $\mathrm{I}(1)^{* *}$ & Hungary & Alföld és Észak & 0,045 & $\mathrm{I}(1) * *$ \\
\hline Germany & Berlin & 0,560 & $\mathrm{I}(1)^{*}$ & Holland & $\begin{array}{c}\text { Noord- } \\
\text { Nederland }\end{array}$ & 0,908 & $\mathrm{I}(1)^{* *}$ \\
\hline Germany & Brandenburg & 0,012 & $\mathrm{I}(1)^{* *}$ & Holland & Oost-Nederland & 0,890 & $\mathrm{I}(1)^{* *}$ \\
\hline Germany & Bremen & 0,963 & $\mathrm{I}(1)^{* *}$ & Holland & West-Nederland & 0,825 & $\mathrm{I}(1) * *$ \\
\hline Germany & Hamburg & 0,906 & $\mathrm{I}(1)^{* *}$ & Holland & Zuid-Nederland & 0,790 & $\mathrm{I}(1)^{* *}$ \\
\hline Germany & Hessen & 0,911 & $\mathrm{I}(1)^{* *}$ & Austria & Ostösterreich & 0,839 & $\mathrm{I}(1)^{* *}$ \\
\hline Germany & $\begin{array}{l}\text { Mecklenburg- } \\
\text { Vorpommern }\end{array}$ & 0,010 & $\mathrm{I}(1)^{* *}$ & Austria & Südösterreich & 0,777 & $\mathrm{I}(1)^{* *}$ \\
\hline Germany & Niedersachsen & 0,908 & $\mathrm{I}(1)^{* *}$ & Austria & Westösterreich & 0,906 & $\mathrm{I}(1)^{* *}$ \\
\hline Germany & $\begin{array}{l}\text { Nordrhein- } \\
\text { Westfalen }\end{array}$ & 0,863 & $\mathrm{I}(1)^{* *}$ & Poland & Centralny & 0,940 & $\mathrm{I}(1)^{* *}$ \\
\hline Germany & Rheinland-Pfalz & 0,883 & $\mathrm{I}(1)^{* *}$ & Poland & Poludniowy & 0,937 & $\mathrm{I}(1)^{* * *}$ \\
\hline Germany & Saarland & 0,787 & $\mathrm{I}(1)^{* *}$ & Poland & Wschodni & 0,860 & $\mathrm{I}(1)^{* *}$ \\
\hline Germany & Sachsen & 0,009 & $\mathrm{I}(1)^{* *}$ & Poland & $\begin{array}{c}\text { Pólnocno- } \\
\text { Zachodni } \\
\end{array}$ & 0,943 & $\mathrm{I}(1)^{* *}$ \\
\hline Germany & Sachsen-Anhalt & 0,007 & $\mathrm{I}(1)^{* *}$ & Poland & $\begin{array}{l}\text { Poludniowo- } \\
\text { Zachodni } \\
\end{array}$ & 0,977 & $\mathrm{I}(1)^{* *}$ \\
\hline Germany & $\begin{array}{l}\text { Schleswig- } \\
\text { Holstein }\end{array}$ & 0,952 & $\mathrm{I}(1)^{* *}$ & Poland & Pólnocny & 0,881 & $\mathrm{I}(1)^{* *}$ \\
\hline Germany & Thüringen & 0,191 & $\mathrm{I}(1)^{* *}$ & Romania & $\begin{array}{l}\text { Macroregiunea } \\
\text { unu }\end{array}$ & 0,365 & $\mathrm{I}(1)^{* *}$ \\
\hline Greece & Voreia Ellada & 0,664 & $\mathrm{I}(1)^{* *}$ & Romania & $\begin{array}{c}\text { Macroregiunea } \\
\text { doi }\end{array}$ & 0,353 & $\mathrm{I}(1)^{*}$ \\
\hline Greece & Kentriki Ellada & 0,473 & $\mathrm{I}(1)^{* *}$ & Romania & $\begin{array}{c}\text { Macroregiunea } \\
\text { trei }\end{array}$ & 0,860 & $\mathrm{I}(1)^{* *}$ \\
\hline Greece & Attiki & 0,671 & $\mathrm{I}(1)^{* *}$ & Romania & $\begin{array}{c}\text { Macroregiunea } \\
\text { patru }\end{array}$ & 0,705 & $\mathrm{I}(1)^{* *}$ \\
\hline Greece & $\begin{array}{c}\text { Nisia Aigaiou, } \\
\text { Kriti } \\
\end{array}$ & 0,486 & $\mathrm{I}(1)^{* *}$ & Finland & Manner-Suomi & 0,961 & $\mathrm{I}(1) * *$ \\
\hline Spain & Noroeste & 0,804 & $\mathrm{I}(1)^{* *}$ & Finland & Åland & 0,976 & $\mathrm{I}(1)^{* *}$ \\
\hline Spain & Noreste & 0,960 & $\mathrm{I}(1)^{* *}$ & Sweden & Östra Sverige & 0,989 & $\mathrm{I}(1)^{* * *}$ \\
\hline
\end{tabular}


Table A1 continued

\begin{tabular}{|c|c|c|c|c|c|c|c|}
\hline Country & Region name & ADF & KPSS & Country & Region name & ADF & KPSS \\
\hline Spain & Noreste & 0,960 & $\mathrm{I}(1)^{* *}$ & Sweden & Östra Sverige & 0,989 & $\mathrm{I}(1) * *$ \\
\hline Spain & $\begin{array}{c}\text { Comunidad de } \\
\text { Madrid } \\
\end{array}$ & 0,708 & $\mathrm{I}(1)^{* *}$ & Sweden & Södra Sverige & 0,971 & $\mathrm{I}(1)^{* *}$ \\
\hline Spain & Centro (ES) & 0,996 & $\mathrm{I}(1)^{* *}$ & Sweden & Norra Sverige & 0,427 & $\mathrm{I}(1)^{* *}$ \\
\hline Spain & Este & 0,875 & $\mathrm{I}(1)^{* *}$ & UK & $\begin{array}{c}\text { North East } \\
\text { (ENGLAND) }\end{array}$ & 0,898 & $\mathrm{I}(1) * *$ \\
\hline Spain & Sur & 0,789 & $\mathrm{I}(1)^{* *}$ & UK & $\begin{array}{c}\text { North West } \\
\text { (ENGLAND) }\end{array}$ & 0,786 & $\mathrm{I}(1) * *$ \\
\hline Spain & Canarias (ES) & 0,757 & $\mathrm{I}(1)^{* *}$ & UK & $\begin{array}{l}\text { Yorkshire and } \\
\text { The Humber }\end{array}$ & 0,756 & $\mathrm{I}(1) * *$ \\
\hline France & Île de France & 0,872 & $\mathrm{I}(1)^{* *}$ & UK & $\begin{array}{l}\text { East Midlands } \\
\text { (ENGLAND) }\end{array}$ & 0,864 & $\mathrm{I}(1)^{* * *}$ \\
\hline France & Bassin Parisien & 0,581 & $\mathrm{I}(1)^{* *}$ & UK & $\begin{array}{l}\text { West Midlands } \\
\text { (ENGLAND) }\end{array}$ & 0,485 & $\mathrm{I}(1) * *$ \\
\hline France & Nord - Pas-de-Calais & 0,759 & $\mathrm{I}(1)^{* *}$ & UK & Eastern & 0,817 & $\mathrm{I}(1)^{* *}$ \\
\hline France & Est & 0,321 & $\mathrm{I}(1)^{* *}$ & UK & London & 0,958 & $\mathrm{I}(1)^{* *}$ \\
\hline France & Ouest & 0,662 & $\mathrm{I}(1)^{* *}$ & UK & South East & 0,764 & $\mathrm{I}(1)^{* *}$ \\
\hline France & Sud-Ouest & 0,861 & $\mathrm{I}(1)^{* *}$ & UK & $\begin{array}{c}\text { South West } \\
\text { (ENGLAND) }\end{array}$ & 0,870 & $\mathrm{I}(1) * *$ \\
\hline France & Centre-Est & 0,871 & $\mathrm{I}(1)^{* *}$ & UK & Wales & 0,828 & $\mathrm{I}(1)^{* *}$ \\
\hline France & Méditerranée & 0,945 & $\mathrm{I}(1)^{* *}$ & UK & Scotland & 0,982 & $\mathrm{I}(1) * *$ \\
\hline Italy & Nord Ovest & 0,575 & $\mathrm{I}(1)^{* *}$ & UK & $\begin{array}{l}\text { Northern } \\
\text { Ireland }\end{array}$ & 0,628 & $\mathrm{I}(1) * *$ \\
\hline
\end{tabular}

Source: own calculation. 